\title{
Edukasi cara mencuci tangan yang baik dan benar sebagai upaya untuk mencegah COVID-19 di Desa Tibang Kecamatan Syiah Kuala
}

\author{
Annisa Ammalia Kiti $\left.{ }^{*}\right)$; Cut Yuliana ${ }^{2}$; Resmila Dewi ${ }^{3}$ \\ $\left.1^{*}\right), 2,3$ Program Studi Farmasi, STIKes Assyifa Aceh, Banda Aceh, Indonesia
}

Email: annisaammaliakiti@stikesassyifaaceh.ac.id

\begin{abstract}
Abstrak: Kebiasaan cuci tangan merupakan salah satu Perilaku Hidup Bersih dan Sehat (PHBS) sebagai upaya untuk menjaga kesehatan agar terhindar dari berbagai penyakit. Tujuan dari program pengabdian masyakat ini yaitu untuk memberikan edukasi kepada masyarakat mengenai cara mencuci tangan yang baik dan benar sesuai anjuran World Health Organization (WHO). Kegiatan Pengabdian Masyarakat ini dilaksanakan pada tanggal 23 Juni 2020 di Desa Tibang, Kecamatan Syiah Kuala, Kota Banda Aceh. Sasaran dari Program ini yaitu Masyarakat Desa Tibang yang berjumlah 40 orang dengan kisaran usia 30-70 Tahun terdiri dari laki-laki dan perempuan. Metode yang dilakukan dalam pelaksanaannya yaitu menggunakan metode ceramah, demonstrasi dan tanya jawab. Secara keseluruhan hasil dari program kegiatan masyarakat ini berjalan dengan lancar, kondusif, dan sesuai prosedur. Kesimpulan dari kegiatan Pengabdian Masyarakat ini diharapkan dapat meningkatkan pemahaman masyarakat Desa Tibang mengenai pentingnya cara mencuci tangan yang baik dan benar sesuai aturan WHO dan diharapkan kegiatan ini juga dapat membantu salah satu Agenda Pemerintah dalam mengurangi penularan wabah COVID-19 di daerah Aceh.
\end{abstract}

Kata kunci: COVID-19, cuci tangan, WHO

Abstract: The habit of washing hands is one of the Clean and Healthy Living Behaviors (PHBS) as an effort to maintain health to avoid various diseases. The purpose of this community service program was to provide education to the societies about how to wash hands properly and correctly according to the recommendations of the World Health Organization (WHO). This Community Service activity was held on June 23, 2020, in Tibang Village, Syiah Kuala District, Banda Aceh. The targets of this program were the Tibang Village Communities, amounting to 40 people with an age range of 30-70 years consisting of men and women. The method used in its implementation were using lectures, demonstrations, question and answer methods. Overall the results of this community activities program were run smoothly, conducive, and according to procedures. The conclusion of this Community Service activity was expected to increase the understanding of the Tibang village community regarding the importance of proper and correct handwashing according to WHO rules and it is hoped that this activity can also help one of the Government Agenda in reducing the transmission of the COVID-19 outbreak in the Aceh region.

Keywords: COVID-19, wash hands, WHO

\section{Pendahuluan}

Pada bulan Desember 2019, dunia dihebohkan dengan munculnya penyakit sistem pernapasan baru di kota Wuhan, Cina yang disebut Coronavirus Disease 2019 (COVID-19). Adapun gejala yang terjadi apabila terinfeksi virus ini diantaranya adalah demam, diare, mual, batuk, sakit kepala, hidung tersumbat, rasa lelah yang berlebihan, hingga mengalami kesulitan bernapas. Bahkan pada kondisi yang 
lebih kritis, infeksi ini dapat menyebabkan pneumonia, gagal ginjal, kerusakan hati akut, kerusakan jantung, sindrom pernapasan akut, hingga menyebabkan kematian,

Penularan COVID-19 pada manusia dapat terjadi melalui droplet orang yang terinfeksi saat batuk, bersin, berbicara, maupun secara kontak langsung dengan orang yang terinfeksi pada jarak kurang dari satu meter. Virus ini menyebar dengan cepat ke seluruh dunia termasuk salah satunya Indonesia. Pada tanggal 2 Maret 2020, COVID-19 pertama kali dilaporkan di Indonesia sebanyak 2 kasus dan seiring waktu terus mengalami peningkatan. Perkembangan selanjutnya yaitu 3 Mei 2020, kasus COVID-19 mengalami peningkatan dengan jumlah kasus sebanyak 11.192 orang positif dengan 845 kematian (Kementerian Kesehatan RI, 2020). Peningkatan jumlah kasus yang cukup signifikan tersebut sangat mengkhawatirkan, sehingga perlu dilakukan pencegahan untuk mengurangi penyebaran virus tersebut.

World Health Organization (WHO) telah menetapkan standar untuk mencegah penyebaran infeksi diantaranya adalah mencuci tangan dengan benar secara teratur. Mencuci tangan menggunakan sabun merupakan salah satu cara paling efektif dalam mencegah penyebaran COVID-19. Hal ini disebabkan karena kandungan sabun terbukti secara klinis mampu membunuh bakteri dan virus penyebab penyakit. Oleh sebab itu, pemerintah juga senantiasa menghimbau kepada masyarakat agar disiplin mencuci tangan untuk melindungi diri dari COVID-19. Namun yang menjadi permasalahannya ialah tidak semua masyarakat mengetahui bagaimana cara mencuci tangan secara baik dan benar seperti yang telah direkomendasikan oleh WHO.

Berdasarkan permasalahan di atas, Tim Dosen STIKes Assyifa Aceh melakukan kegiatan pengabdian kepada masyarakat dengan memberikan sosialisasi cara mencuci tangan yang baik dan benar. Kegiatan ini bertujuan untuk memberikan edukasi kepada masyarakat khususnya Desa Tibang, mengenai cara mencuci tangan yang baik dan benar sesuai anjuran WHO sehingga dapat mengurangi penyebaran COVID-19.

\section{Metode}

Program pengabdian masyararakat ini dilaksanakan di Desa Tibang Kec. Syiah Kuala Kota Banda Aceh pada hari Selasa tanggal 23 Juni 2020. Sasaran dari program ini adalah masyarakat di Desa Tibang yang berjumlah 40 orang dengan kelompok usia 30 - 70 tahun, berjenis kelamin laki-laki dan perempuan.

Pelaksanaan kegiatan pengabdian kepada masyarakat dilakukan dengan metode :

1. Ceramah, yaitu menjelaskan pentingnya mencuci tangan menurut standar WHO yaitu 6 langkah cuci tangan yang baik dan benar;

2. Demonstrasi, yaitu memberikan demonstrasi dengan mempraktikkan langsung cara melakukan 6 langkah cuci tangan yang baik dan benar sesuai standar WHO;

3. Tanya Jawab, yaitu menanyakan bagaimana pemahaman masyarakat Desa Tibang tentang 6 langkah cuci tangan yang baik dan benar serta memberikan kesempatan kepada masyarakat bila masih ada hal belum dipahami tentang sosialisasi 6 langkah cara cuci tangan yang baik dan benar sesuai anjuran WHO.

Enam langkah mencuci tangan yang baik dan benar menurut WHO yaitu sebagai berikut: (pada praktiknya Tim Abdimas STIKes Assyifa Aceh mengganti sabun dengan belau (biru) yang berfungsi untuk memudahkan masyarakat dalam memahami prosedur tersebut): 
1. Tuangkan cairan sabun pada telapak tangan kemudian gosok sampai berbusa kemudian usap kedua telapak tangan secara bersamaan

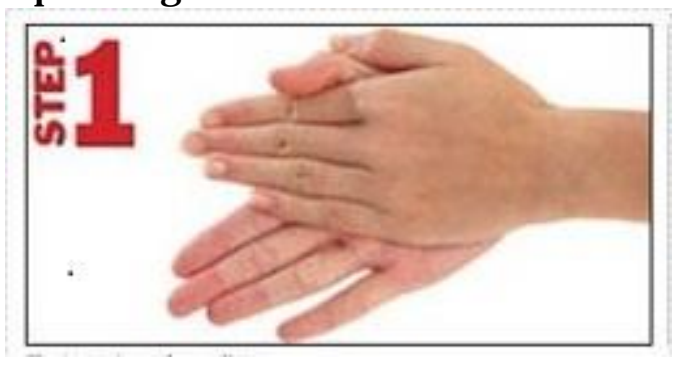

2. Usap dan gosok bagian punggung tangan kiri dan kanan secara bergantian

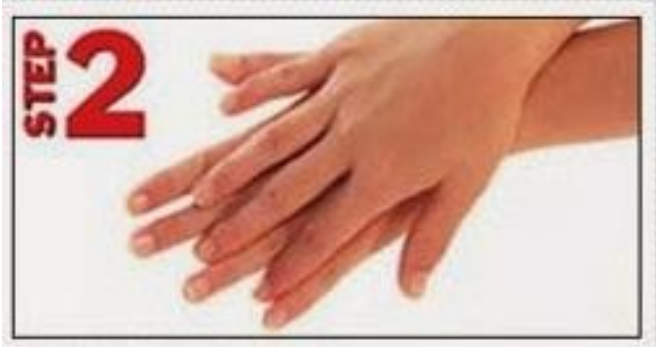

3. Usap dan gosok sela-sela jari tangan kiri dan kanan secara bergantian

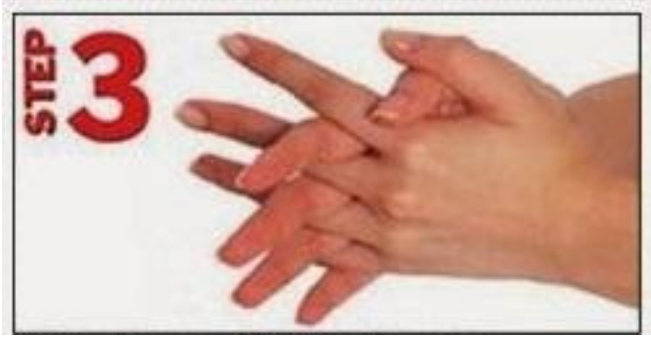

4. Gosok ujung jari kiri dan kanan dengan posisi saling menguci secara bergantian

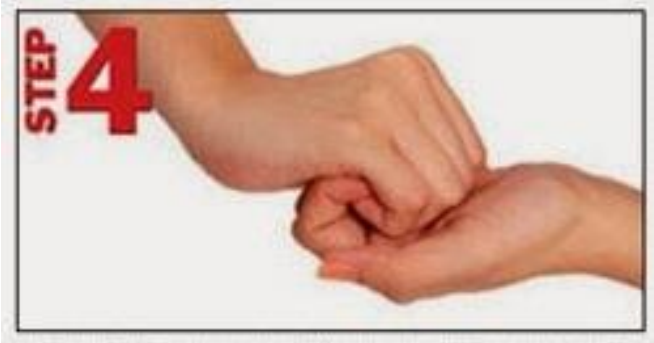

5. Gosok dan putar kedua ibu jari kiri dan kanan secara bergantian

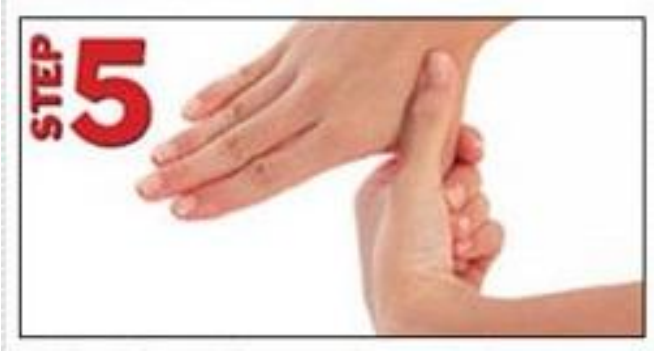


6. Letakkan ujung jari ke telapak tangan kiri dan kanan secara bergantian kemudian gosok perlahan

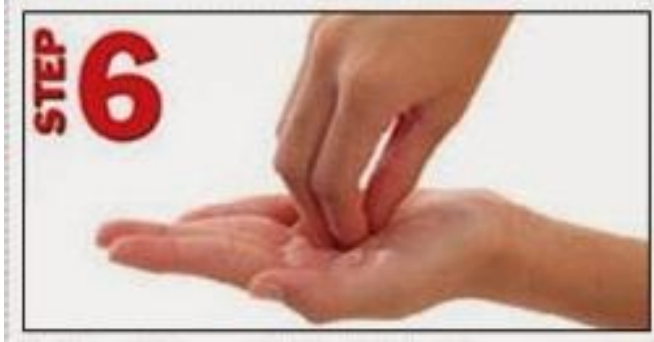

\section{Hasil dan Pembahasan}

Tim Dosen STIKes Assyifa Aceh telah melaksanakan pengabdian kepada masyarakat (Abdimas) bertema sosialisasi 6 langkah cuci tangan yang baik dan benar sesuai anjuran WHO pada Bulan Juni 2020. Pelaksanaan Abdimas ini ditargetkan terhadap masyarakat kelompok usia $30-70$ tahun, berjenis kelamin laki-laki dan perempuan yang berdomisili di Desa Tibang, Kecamatan Syiah Kuala, Kota Banda Aceh. Sosialisasi ini merupakan bentuk kepedulian Dosen-Dosen di STIKes Assyifa Aceh yang berkeinginan untuk turut mensukseskan salah satu Program Pemerintah dalam mencegah penyebaran COVID-19 di Indonesia, khusunya di daerah Provinsi Aceh.

Sosialisasi ini diawali dengan presentasi singkat mengenai COVID-19 (Gambar 1). Selanjutnya kegiatan dilakukan dengan mendemonstrasikan sekaligus memberi penjelasan secara langsung tahaptahap mencuci tangan yang benar di hadapan masyarakat. Tim Dosen STIKes Assyifa Aceh menggunakan belau sebagai pengganti sabun untuk membantu memberi pemahaman kepada masyarakat mengenai esensialnya mencuci tangan sesuai 6 urutan yang sudah ditunjukkan oleh dua orang perwakilan Dosen (Gambar 2). Penggunaan belau ini merupakan strategi yang sangat membantu Tim Dosen untuk menyampaikan pesan tersebut kepada masyarakat. Masyarakat Desa Tibang sangat fokus mendengarkan penjelasan dari Tim Dosen sambil mengamati prosedur yang dicontohkan. Setelah itu dilanjutkan dengan sesi tanya jawab (Gambar 3).

Tim Abdimas STIkes Assyifa Aceh kemudian berpesan kepada masyarakat agar mereka dapat selalu menerapkan prosedur yang sudah didemonstrasikan. Selain itu, Tim juga mengingatkan mereka untuk menginformasikan prosedur tersebut kepada keluarga, teman dan masyarakat lain di Desa Tibang yang tidak berkesempatan hadir pada kegiatan hari itu. Diharapkan pengetahuan yang sudah disosialisasikan oleh Tim kepada perwakilan masyarakat pada kegiatan Abdimas ini dapat tersampaikan secara menyeluruh kepada semua penduduk di Desa Tibang, sehingga hal sederhana yang sudah disosialisasikan itu dapat meminimalisir penularan COVID-19 di Desa tersebut.

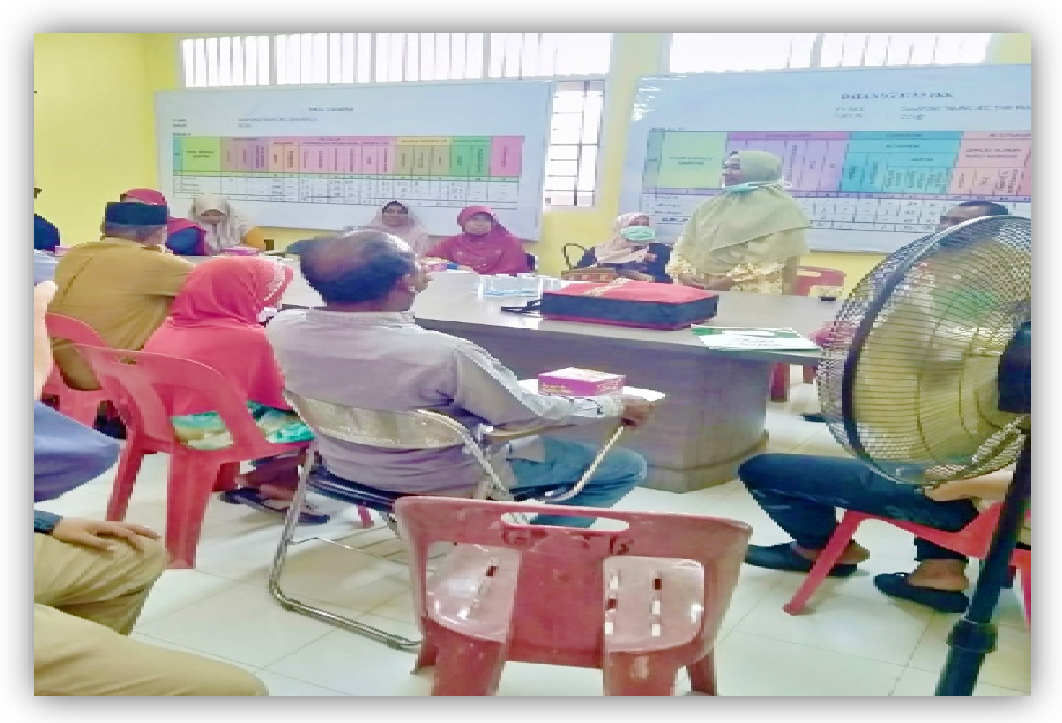

Gambar 1. Presentasi singkat mengenai COVID-19 


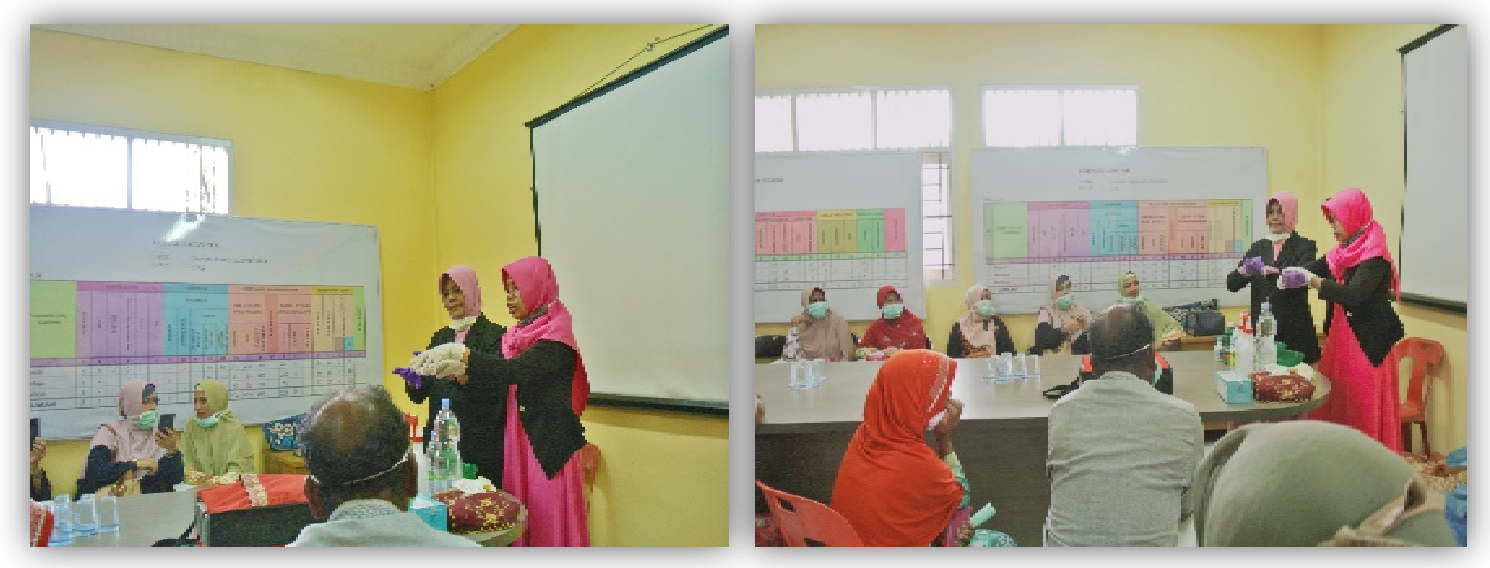

Gambar 2. Demonstrasi 6 langkah mencuci tangan yang baik dan benar sesuai anjuran WHO

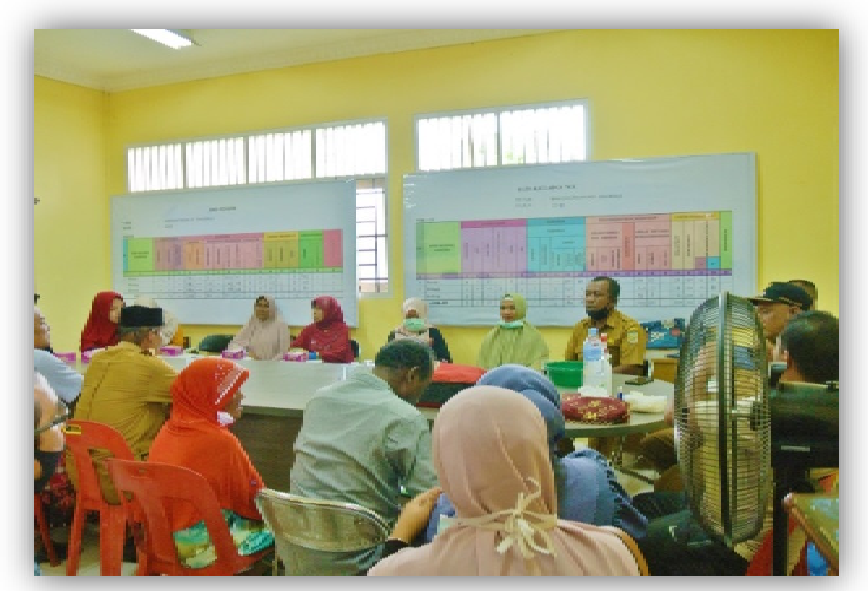

Gambar 3. Sesi tanya jawab dengan masyarakat Desa Tibang

Dua orang perwakilan mahasiswa STIKes Assyifa Aceh juga dilibatkan dalam kegiatan Abdimas tersebut. Diharapkan melalui aksi ini, mahasiswa sebagai kandidat intelektual dapat belajar menjadi Agent of Change yang dapat memberi perubahan berharga di tengah-tengah masyarakat.

Setelah sosialisasi telah selesai dilakukan, Tim Dosen STIKes Assyifa Aceh dengan bantuan dua orang mahasiswa memasangkan spanduk mengenai 6 langkah cara mencuci tangan yang benar di depan Kantor Keuchik Desa Tibang (Gambar 4). Pemasangan spanduk ini bertujuan agar semua penduduk Desa Tibang lainnya yang tidak dapat hadir pada kegiatan ini juga dapat teredukasi dan mudah memahami prosedur tersebut.
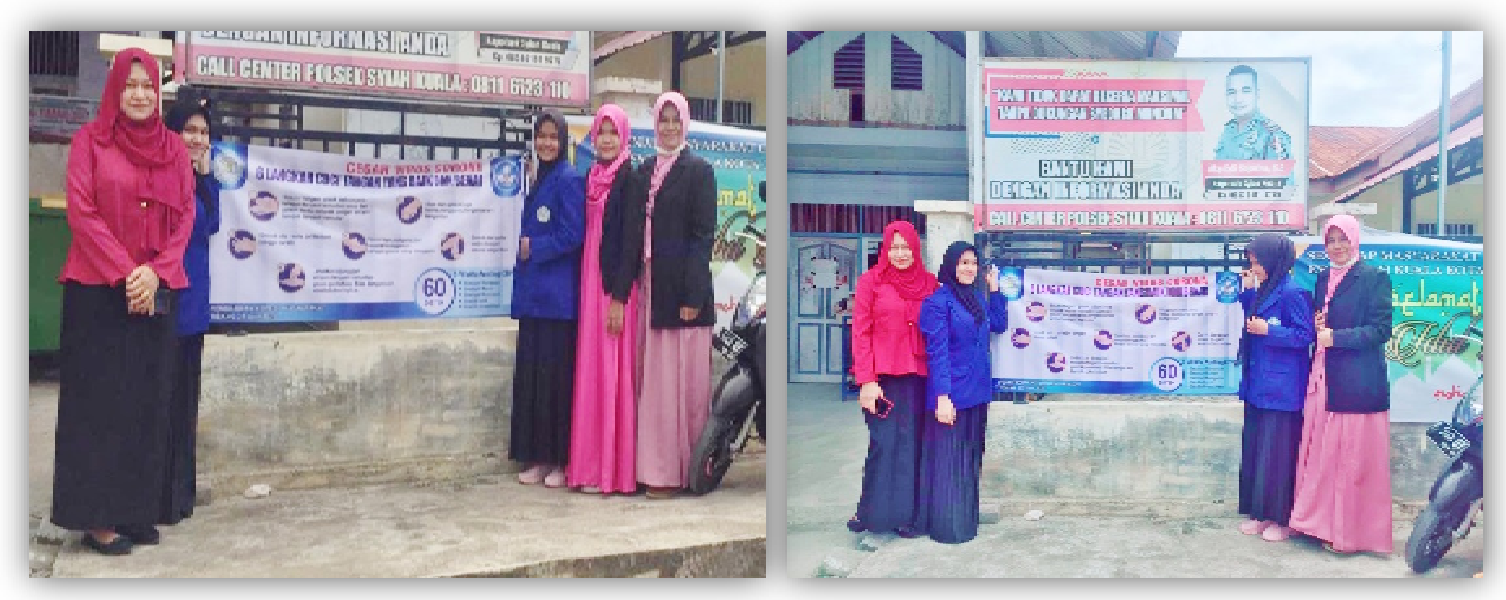

Gambar 4. Pemasangan spanduk di depan Kantor Keuchik Desa Tibang 


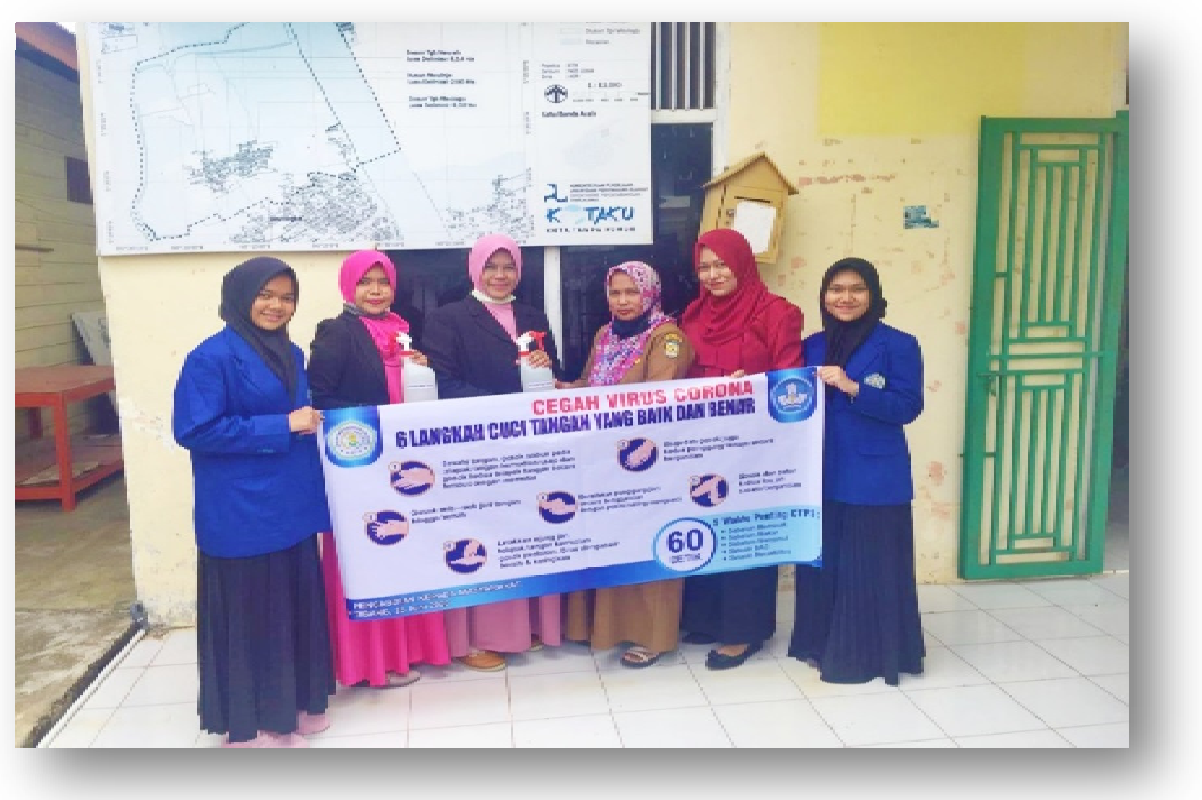

Gambar 5. Foto bersama perwakilan Aparatur Desa Tibang

Diharapkan setelah dilaksanakannya sosialisasi, setiap masyarakat yang ikut serta dalam kegiatan ini dapat mempraktikkan 6 langkah cuci tangan yang benar sesuai himbauan WHO. Masyarakat juga didorong untuk ikut berpartisipasi sebagai agen sosialisator di lingkungannya, sehingga dapat turut berkontribusi dalam mengurangi penularan COVID-19. Hal sederhana namun efektif dalam pencegahan penyebaran wabah COVID-19 di Provinsi Aceh pada umumnya dan Desa Tibang secara khusus.

Keputusan Menteri Kesehatan Republik Indonesia Nomor: Hk.01.07Menkes/382/2020 telah menyebutkan bahwa setiap masyarakat berperan penting dalam memutus mata rantai penularan COVID-19 agar tidak menimbulkan sumber penularan baru/cluster pada tempat-tempat dimana terjadinya pergerakan orang, interaksi antar manusia dan berkumpulnya banyak orang. Masyarakat harus dapat beraktivitas kembali dalam situasi pandemi COVID-19 dengan beradaptasi pada kebiasaan baru yang lebih sehat, lebih bersih, dan lebih taat, yang dilaksanakan oleh seluruh komponen yang ada di masyarakat serta memberdayakan semua sumber daya yang ada.

\section{Kesimpulan}

Tim Dosen STIKes Assyifa Aceh telah melaksanakan pengabdian kepada masyarakat di Desa Tibang, Kecamatan Syiah Kuala, Kota Banda Aceh. Setelah dilakukan Kegiatan Pengabdian Masyarakat ini diharapkan dapat meningkatkan pemahaman masyarakat Desa Tibang mengenai pentingnya cara mencuci tangan yang baik dan benar sesuai aturan WHO dan diharapkan kegiatan ini juga dapat membantu salah satu Agenda Pemerintah dalam mengurangi penularan wabah COVID-19 di daerah Aceh.

\section{Ucapan Terima Kasih}

Terima kasih yang tulus kami ucapkan kepada Bapak Keuchik dan Aparatur beserta semua penduduk Desa Tibang Kecamatan Syiah Kuala, Kota Banda Aceh yang telah menerima Tim Abdimas STIKes Assyifa Aceh dan bekerja sama dengan baik demi terselenggaranya kegiatan ini. 


\section{Daftar Pustaka}

Keputusan Menteri Kesehatan Republik Indonesia. 2020. Protokol kesehatan bagi masyarakat di tempat dan fasilitas umum dalam rangka pencegahan dan pengendalian Corona Virus Disease 2019 (Covid-19). Jakarta: Kementerian Kesehatan RI.

Kementrian Kesehatan RI. 2020. Situasi Terkini Perkembangan Coronavirus Disease (Covid-19) 4 Mei 2020. Jakarta: Kementrian Kesehatan RI.

Sinaga, L. R. V., Munthe, S. A., \& Bangun, H. A. 2020. Sosialisasi Perilaku Cuci Tangan Pakai Sabun di Desa Sawo Sebagai Bentuk Keepedulian Terhadap Masyarakat di Tengah Mewabahnya Virus Covid-19. Jurnal Abdimas Mutiara, 1(2): 19-28.

Sumaiyah, S., Marianne, M., Nasution, E. S., Pertiwi, D., \& Nugraha, S. E. 2020. Sosialisasi Langkah Cuci Tangan Yang Benar Guna Mewujudkan Masyarakat Sehat Di Sman 2 Sibolga. Jurnal Pengabdian UntukMu NegeRI, 4 (1): 129-132.

World Health Organization. 2005. Pocket of Hospital Care for Children: Guideline for the Management of Common Illnesses with Limited Resources. Geneva: WHO Press. 